\title{
PENGARUH KONSENTRASI ASAM MONOKLORO ASETAT DALAM PROSES KARBOKSIMETILASI KITOSAN TERHADAP KARBOKSIMETIL KITOSAN YANG DIHASILKAN
}

\author{
Jamal Basmal"), Agung Prasetyo"), dan Yusro Nuri Fawzya")
}

\begin{abstract}
ABSTRAK
Percobaan pembuatan karboksimetil kitosan (CMCts) telah dilakukan dengan variasi jumlah asam monokloro asetat. Rasio kitosan : asam monokloro asetat yang digunakan selama eterifikasi $1: 0,9 ; 1: 1,1 ; 1: 1,3$ dan $1: 1,5(b / b)$. Eterifikasi dilakukan pada suhu $90^{\circ} \mathrm{C}$ selama 4 jam. Hasil percobaan menunjukkan bahwa jumlah asam monokloro asetat sangat berpengaruh terhadap kualitas dan kuantitas $\mathrm{CMCts}$ yang dihasilkan. Rasio terbaik berdasarkan nilai kekentalan, kadar air dan kadar abu ditemukan pada perlakuan penggunaan asam monokloro asetat dengan rasio kitosan : asam monokloro asetat 1:0,9 (b/b) yang menghasilkan rendemen sebesar $129,4 \%$, kadar air $9,7 \%$, kadar abu $1,7 \%$, nilai kekentalan $49,3 \mathrm{cPs}$, tingkat kelarutan membutuhkan 9,85 $\mathrm{ml}$ air untuk melarutkan $1 \mathrm{~g} \mathrm{CMCts}$ dan derajat substitusi sebesar 0,89.
\end{abstract}

\begin{abstract}
Effect of monochloro acetic acid concentration during the carboxymethylation process of chitosan on the production of carboxymethyl chitosan produced. By: Jamal Basmal, Agung Prasetyo, and Yusro Nuri Fawzya

An experiment to produce carboxymethyl chitosan (CMCts) was carried out using monochloro acetic acid concentrations as a variable factor. The ratio of chitosan : monochloro acetic acid applied were 1:0.9; $1: 1.1 ; 1: 1.3$ dan $1: 1.5(w / w)$. Etherification process was executed at $90^{\circ} \mathrm{C}$ for 4 hours. Result of the experiment showed that monochloro acetic acid showed significant effect on the quality and quantity of CMCts. Based on viscosity, moisture content and ash content, the best ratio of chitosan : monochloro acetic acid was 1:0.9 (w/w) giving yield of 129,4\%, moisture content of $9.7 \%$, ash content of $1.7 \%$, viscosity of $49.3 \mathrm{cPs}$, solubility of $9.85 \mathrm{~m} /$ water to dilute $1 \mathrm{~g}$ CMCts and degree of substitution of 0.89 .
\end{abstract}

KEYWORDS: chitosan, carboxymethyl chitosan, carboxymethylation, and monochloro acetic acid

\section{PENDAHULUAN}

Karboksimetil kitosan (CMCts) merupakan salah satu turunan dari kitin yang diperoleh melalui suatu proses eterifikasi (karboksimetilasi) alkalis kitosan dengan asam monokloro asetat. CMCts ini mempunyai kelebihan dari kitin maupun kitosan karena CMCts mudah larut di dalam air dibandingkan dengan kitin maupun kitosan sehingga mudah diaplikasikan pada industri pangan maupun nonpangan, disamping itu CMCts bersifat biodegradable, biocompatible dan tidak beracun. Pada buah-buahan CMCts dapat memperpanjang daya simpan dan menjaga buah-buahan tetap segar selama penyimpanan. Kelebihan lain $\mathrm{CMCts}$ adalah mudah diaplikasikan untuk mengikat tembaga $\left(\mathrm{Cu}^{+}\right)$pada air limbah, sebagai antikoagulan dan juga sebagai zat antimikroba (Davies et al., 1989).
Teknik pembuatan CMCts adalah dengan mereaksikan kitosan dengan asam monokloro asetat pada suasana alkali. Gugus karboksimetil $\left(\mathrm{CH}_{2} \mathrm{COO}\right)$ dari asam monokloro asetat mensubstitusi gugus hidroksil $\left(\mathrm{OH}^{-}\right)$dan gugus amin $\left(\mathrm{NH}_{2}\right)$. Derajat substitusi setelah proses eterifikasi kitosan bervariasi antara 0,6 sampai 1,0 . Kisaran nilai $\mathrm{pH}$ kelarutan di atas 6 atau di bawah 2 . Di antara $\mathrm{pH} 2$ sampai 6 akan membentuk gel. Garam natrium pada CMCts, larut di dalam air pada pH 8 (Davies et al., 1989). Selanjutnya dilaporkan bahwa pemberian CMCts dengan konsentrasi 50.000 ppm pada makanan tikus selama 14 hari tidak mempengaruhi kehidupan tikus.

Secara prinsip reaksi pembentukan $\mathrm{CMCts}$ adalah reaksi asam basa. Diketahui bahwa asam dalam suatu zat cenderung untuk melepaskan proton (proton donor) sedangkan basa cenderung untuk mengikat proton (proton aseptor). Asam monokloro asetat $\left(\mathrm{Cl}^{-} \mathrm{CH}_{2}-\right.$

\footnotetext{
Peneliti pada Balai Besar Riset Pengolahan Produk dan Bioteknologi Kelautan dan Perikanan

*) Mahasiswa Fakultas Farmasi, Universitas Pancasila
} 
$\mathrm{C}(=\mathrm{O})-\mathrm{OH})$ merupakan asam organik lemah yang mudah terdisosiasi. Pada reaksi pembentukan CMCts, kitosan dibuat dalam suasana alkali yang telah mengikat ion $\mathrm{Na}^{+}$, sehingga pada waktu direaksikan dengan asam (monokloro asetat) terjadi pertukaran ion yakni ion $\mathrm{Na}^{+}$yang mudah larut dalam air akan terikat dengan ion $\mathrm{Cl}^{-}$yang dilepaskan oleh asam monokloro asetat membentuk larutan garam $\mathrm{NaCl}$, sedangkan kitosan yang telah melepaskan ion $\mathrm{Na}^{+}$ akan bersifat reaktif terhadap gugus karboksil dari asam monokloro asetat sehingga membentuk CMCts.

Beberapa faktor yang berpengaruh dalam pembentukan CMCts adalah kualitas kitosan, jumlah alkalis kitosan yang diperoleh (proses alkalinisasi), konsentrasi asam monokloro asetat, dan suhu eterifikasi. Ketepatan konsentrasi asam monokloro asetat sangat berperan dalam pembentukan $\mathrm{CMCts,}$ kelebihan asam monokloro asetat akan menyebabkan terjadinya proses hidrolisis lebih lanjut dan terbentuknya sodium-glikolat, sebaliknya apabila kekurangan asam monokloro asetat akan menyebabkan pembentukan CMCts tidak sempurna. Pada penelitian ini perlakuan konsentrasi asam monokloro asetat merupakan faktor utama untuk mendapatkan CMCts yang berkualitas. Hasil percobaan yang dilakukan oleh Basmal et al. (2005) menemukan bahwa suhu optimal untuk eterifikasi alkalis kitosan adalah $90^{\circ} \mathrm{C}$.

\section{BAHAN DAN METODE}

\section{Bahan}

Bahan yang digunakan untuk pembuatan kitosan adalah kulit/cangkang rajungan yang telah dikeringkan dan berasal dari Kabupaten Cirebon, Jawa Barat. Kitosan diperoleh dari ekstraksi kitin (Dwiyitno et al., 2004). Kitin dideasetilasi menggunakan basa kuat, kemudian dinetralkan dan dikeringkan di bawah sinar matahari. Bahan kimia yang digunakan adalah larutan sodium hidroksida, asam monokloro asetat dan asam klorida.

\section{Metode}

Kitosan yang telah diperoleh kemudian dialkalinisasi dengan menggunakan larutan $\mathrm{NaOH}$ $50 \%$ selama 2 jam untuk selanjutnya dilakukan proses eterifikasi menggunakan asam monokloro asetat dengan variasi rasio antara kitosan dan asam monokloro asetat $(\mathrm{b} / \mathrm{b})$ adalah 1 bagian kitosan dengan 0,$9 ; 1,1 ; 1,3$, dan 1,5 bagian asam monokloro asetat. Suhu eterifikasi yang digunakan $90^{\circ} \mathrm{C}$ selama 4 jam.

Karboksimetil kitosan (kitosan larut air) yang diperoleh dianalisis kualitasnya yang meliputi: kadar air dan kadar abu (Horwitz, 1980), kekentalan (pada konsentrasi $1 \%$ ) menggunakan alat viskometer merek Brookfield, derajat substitusi (DS) (Anon., 1998), dan rendemen. Tingkat kelarutan ditentukan dengan metode filtrat (Aumeilia, 2004) dengan cara melarutkan karboksimetil kitosan dalam air sambil diaduk selama 1 jam dengan pengaduk magnetik pada suhu kamar sampai jenuh, lalu disaring dengan kertas saring. Filtrat diambil 1,0 ml dimasukkan ke cawan yang telah ditimbang sampai bobot tetap $\left(W_{0}\right)$, kemudian diuapkan dalam oven. Selanjutnya cawan didinginkan dalam desikator dan ditimbang $\left(W_{1}\right)$. Jumlah karboksimetil kitosan yang larut adalah banyaknya karboksimetil kitosan yang ada dalam cawan setelah diuapkan $\left(W_{0}-W_{1}\right) \times 100 \%$.

Table 1. Deskripsi kelarutan berdasarkan Farmakope Indonesia

Tabel 1. Description of solubility based on Indonesian Farmakope

\begin{tabular}{lc}
\hline Parameter deskriptif/Descriptive parameters & $\begin{array}{c}\text { Jumlah pelarut yang diperlukan untuk } \\
\text { melarutkan 1 bagian zat/Total solvent to } \\
\text { dilute 1 part of substance }\end{array}$ \\
\hline Sangat mudah larut/Very easy to dissolve & $<1$ \\
Mudah larut/Easy to dissolve & $1-10$ \\
Larut/Dissolved & $10-30$ \\
Agak sukar larut/Slightly difficult to dissolve & $30-100$ \\
Sukar larut/Difficult to dissolve & $100-1000$ \\
Sangat sukar larut/Very difficult to dissolve & $1000-10000$ \\
Tidak larut/Undissolved & $>10000$ \\
\hline
\end{tabular}

Sumber/Source: Anon., (1995) 




Rasio kitosan : asam monokloro asetat/ Ratio of chitosan : monochloro acetic acid

Gambar 1. Rendemen karboksimetil kitosan.

Figure 1. Yield of carboxymethyl chitosan.

\section{HASIL DAN BAHASAN}

\section{Rendemen}

Rendemen CMCts yang diperoleh dari hasil perlakuan variasi asam monokloro asetat berkisar antara $108,3 \%$ sampai $129,4 \%$ dengan nilai tertinggi ditemukan pada perlakuan rasio antara kitosan : asam monokloro asetat 1:0,9 (b/b) yaitu $129,4 \%$ sedangkan terendah pada perlakuan kitosan : asam monokloro asetat $1: 1,5(\mathrm{~b} / \mathrm{b})$ yaitu $108,3 \%$. Terjadinya peningkatan rendemen $\mathrm{CMCts}$ disebabkan oleh adanya substitusi gugus hidroksil $\left(\mathrm{OH}^{-}\right)$dan gugus amin $\left(\mathrm{NH}_{2}\right)$ dengan gugus karboksil $\left(\mathrm{CH}_{2} \mathrm{COO}\right)$ dari asam monokloro asetat selama proses eterifikasi dilakukan.

Pada Gambar 1 terlihat adanya perbedaan rendemen pada masing-masing perlakuan. Nilai rendemen tertinggi ditemukan pada perlakuan rasio kitosan : asam monokloro asetat 1:0,9 (b/b) dan yang terendah pada rasio perlakuan kitosan : asam monokloro asetat 1:1,5 (b/b). Peningkatan jumlah asam monokloro asetat telah menurunkan jumlah CMCts yang terbentuk. Hal ini kemungkinan disebabkan oleh terlalu kuatnya konsentrasi asam sehingga sejumlah gugus karboksil dari asam monokloro asetat tidak bereaksi sempurna pada proses pembuatan CMCts. Kompetisi reaksi subtitusi ion $\mathrm{Cl}^{-}$dari asam monokloro asetat dengan kelebihan sodium hidroksida pada pembentukan kitosan alkalis akan menghasilkan garam-garam kimia seperti sodium klorida. Pada ilustrasi di bawah ini dapat dilihat reaksi pembentukan garam sodium klorida dan sodium glikolat (Gambar 2).

Ternyata peningkatan jumlah asam monokloro asetat yang ditambahkan selama proses eterifikasi tidak dapat meningkatkan jumlah CMCts. Hal ini kemungkinan disebabkan sebagian besar asam

$$
\begin{array}{lll}
\text { Kitosan- }-\mathrm{OH} & \rightarrow & \text { Kitosan-ONa } \\
\text { Kitosan-ONa}+\mathrm{ClCH}_{2} \mathrm{COOH} & \rightarrow & \text { Kitosan-O- } \mathrm{CH}_{2} \mathrm{COONa}+\mathrm{NaCl}+2 \mathrm{H}_{2} \mathrm{O} \\
\mathrm{ClCH}_{2} \mathrm{COOH}+2 \mathrm{NaOH} & \rightarrow & \begin{array}{l}
\text { HOCH } \\
\text { (sodium glikolat) }+ \text { (garam) }
\end{array}
\end{array}
$$

Gambar 2. Reaksi pembentukan garam sodium klorida dan sodium glikolat.

Figure 2. Reaction of chitosan to form sodium chloride and sodium glycolate. 
monokloro asetat telah bereaksi dengan kelebihan sodium hidroksida yang diberikan pada saat proses pemeraman menggunakan larutan $\mathrm{NaOH} 50 \%$ selama 2 jam. Disamping itu, kemungkinan lain adalah sistem penyaringan yang dilakukan tidak sempurna, penyaringan dilakukan menggunakan filter plankton net dengan ukuran 200 mesh, sehingga banyak CMCts yang tidak dapat melewati filter plankton net dan sebagai akibatnya pada tahap penarikan $\mathrm{CMCts}$ dengan isopropil alkohol yang tertarik hanya $\mathrm{CMCts}$ yang memperoleh lebih sedikit dibandingkan dengan perlakuan laninnya. Hasil uji korelasi antar perlakuan ditemukan persamaan garis dengan nilai $Y=-11,872 X$ $+171,04$ dengan nilai $r^{2}=0,97$. Dari persamaan tersebut dapat diartikan bahwa penambahan jumlah asam monokloro asetat akan langsung menurunkan secara linier nilai rendemen CMCts yang dihasilkan. Bader \& Birkholz (1977) menyatakan bahwa rendemen tertinggi pada waktu pembentukan CMCts akan terjadi pada ratio kitosan alkalis : asam monokloro asetat 1:0,9.

\section{Kadar Air}

Nilai kadar air CMCts bervariasi antara 9,7\% sampai $9,9 \%$ dengan nilai tertinggi ditemukan pada perlakuan rasio kitosan : asam monokloro asetat 1:1,5 b/b sebesar $9,9 \%$, sedangkan yang terendah pada perlakuan rasio kitosan : asam monokloro asetat 1:0,9 b/b sebesar 9,7\%. Pada Gambar 3 dapat dilihat nilai kadar air masing-masing perlakuan.

Pada Gambar 3 dapat dilihat bahwa nilai kadar air meningkat paralel dengan peningkatan jumlah asam monokloro asetat yang digunakan. Perbedaan kadar air antar perlakuan penggunaan asam monokloro asetat dari nilai yang terkecil hingga yang terbesar sebesar $0,17 \%$. Telah diketahui bahwa kadar air di dalam polisakarida dapat dibagi menjadi tiga bagian yaitu kadar air bebas, kadar air terikat di antara sel dan kadar air yang berada di dalam sel. Penarikan kadar air menggunakan sinar matahari sangat tergantung pada tingkat kelembaban udara di sekeliling CMCts yang sedang dikeringkan. Sejumlah air yang paling mudah dihilangkan pada kitosan untuk pertama kalinya adalah air bebas, kemudian diikuti oleh air yang terikat antara sel CMCts. Telah diketahui pula bahwa asam monokloro asetat merupakan jenis asam yang mudah menarik air dari lingkungan sekitarnya. Perlakuan rasio kitosan : asam monokloro asetat 1:1,5 mempunyai nilai kadar air yang lebih tinggi dibandingkan dengan perlakuan lainnya. Hal ini mungkin disebabkan jumlah gugus karboksimetil ($\mathrm{CH}_{2} \mathrm{COO}^{-}$) yang berikatan dengan kitosan lebih banyak sehingga pada saat dikeringkan jumlah air di dalam CMCts yang keluar lebih sedikit dibandingkan dengan rasio pemakaian asam monokloro asetat yang lebih kecil. Ilustrasi penarikan air pada permukaan $\mathrm{CMCts}$ dapat dilihat pada Gambar 4 (Andales, 1981).



Gambar 3. Nilai kadar air karboksimetil kitosan.

Figure 3. Moisture content of carboxymethyl chitosan. 


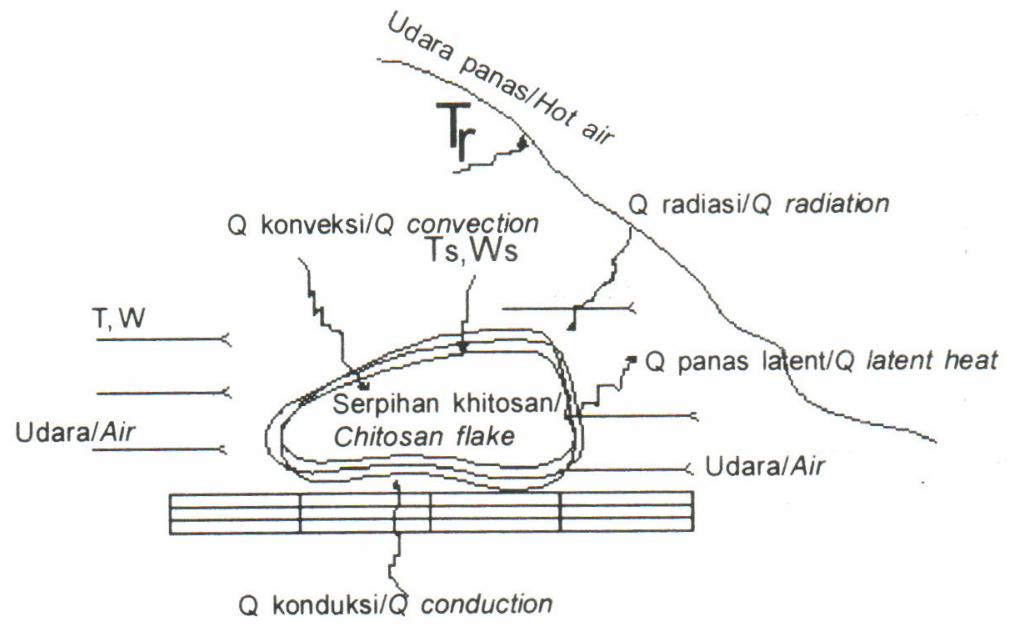

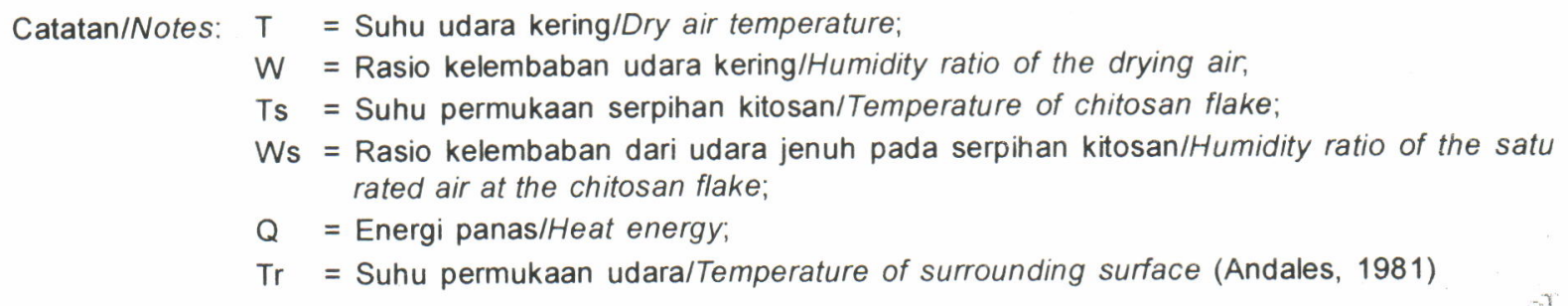

Gambar 4. Ilustrasi penguapan air pada serpihan CMCts.

Figure 4. Illustration of water vapour on the surface of carboxymethyl chitosan.

Diketahui bahwa pengaruh lingkungan selama pengeringan $\mathrm{CMCts}$ adalah sama, oleh sebab itu adanya perbedaan kadar air pada masing-masing perlakuan disebabkan oleh konsentrasi asam monokloro asetat yang diberikan selama proses eterifikasi. Telah diketahui bahwa asam monokloro asetat bersifat hidrofilik yakni mudah menarik air dari udara sekelilingnya. Semakin banyak jumlah asam monokloro asetat yang diberikan pada waktu proses eterifikasi akan lebih banyak air yang ditarik dari udara karena asam monokloro asetat bersifat higroskopis. Perlakuan eterifikasi dengan rasio kitosan : asam monokloro asetat $1: 1,5(\mathrm{~b} / \mathrm{b})$ mempunyai kadar air lebih tinggi dibandingkan dengan perlakuan rasio kitosan : asam monokloro asetat $1: 0,9(\mathrm{~b} / \mathrm{b})$, di samping faktor tersebut di atas adanya kelebihan garam (sodium klorida dan sodium glikolat) yang merupakan hasil samping reaksi antara kitosan alkalis dengan asam monokloro asetat yang menempel pada permukaan serpihan CMCts dapat meningkatkan kadar air produk CMCts yang dihasilkan selama penyimpanan.

\section{Kadar Abu}

Kadar abu pada masing-masing perlakuan bervariasi dari $1,72 \%$ sampai $2,04 \%$. Pada Gambar 5 dapat dilihat variasi kadar abu CMCts setelah mendapatkan perlakuan penambahan asam monokloro asetat.

Pada Gambar 5 dapat dilihat nilai kadar abu yang terendah ditemukan pada perlakuan eterifikasi menggunakan rasio kitosan : monokloro asetat $(1: 0,9)$ (b/b) sebesar $1,7 \%$ dan yang tertinggi ditemukan pada perlakuan eterifikasi menggunakan rasio kitosan : monokloro asetat $(1: 1,5)(\mathrm{b} / \mathrm{b})$ sebesar $2,04 \%$. Hasil pengujian menunjukkan bahwa sebelum mendapatkan perlakuan sebesar $1,1 \%$ dan setelah menjadi CMCts nilai kadar abu meningkat untuk semua perlakuan. Adanya peningkatan kadar abu untuk semua perlakuan kemungkinan disebabkan oleh kelebihan ion $\mathrm{Na}^{+}$di dalam kitosan alkalis dan tidak terjadinya reaksi sempurna antara kitosan alkalis dengan asam monokloro asetat. Terbukti bahwa jumlah asam monokloro asetat yang diberikan pada waktu eterifikasi berpengaruh terhadap peningkatan jumlah kadar abu pada CMCts.

\section{Nilai Kekentalan}

Nilai kekentalan $\mathrm{CMCts}$ yang diperoleh berkisar antara $16,4 \mathrm{cPs}$ sampai $49,3 \mathrm{cPs}$ sebagaimana ditunjukkan pada Gambar 6 . 


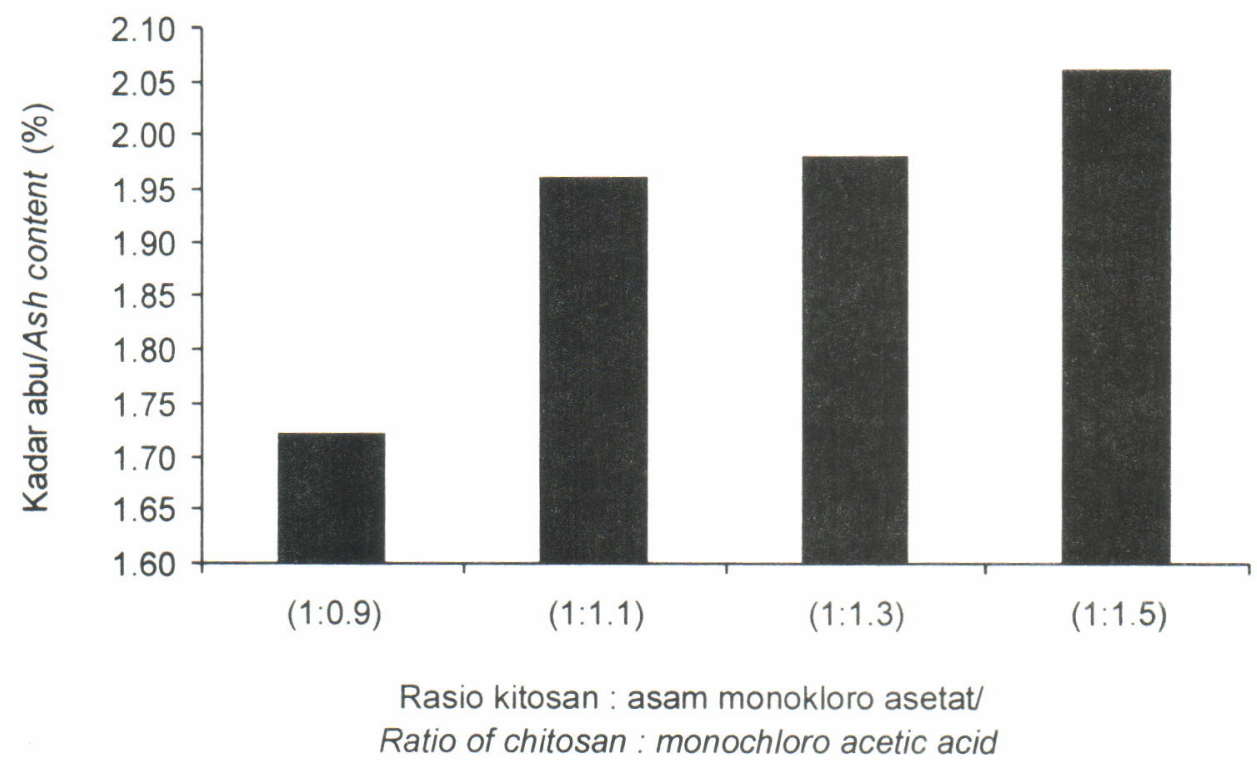

Gambar 5. Nilai kadar abu karboksimetil kitosan. Figure 5. Ash content of carboxymethyl chitosan.

Terlihat bahwa jumlah asam monokloro asetat yang diberikan selama proses eterifikasi kitosan memberikan pengaruh yang nyata terhadap nilai kekentalan $\mathrm{CMCts}$ yang dihasilkan. Nilai kekentalan tertinggi diperoleh dari rasio kitosan : asam monokloro asetat 1:0,9 (b/b) sebesar $49,3 \mathrm{cPs}$ dan terendah pada perlakuan rasio kitosan : asam monokloro asetat 1:1,5 (b/b) sebesar 16,4 cPs. Peningkatan jumlah asam monokloro asetat yang diberikan menyebabkan terjadinya penurunan nilai kekentalan CMCts. Nilai kekentalan kitosan sebelum mendapatkan perlakuan sebesar $571 \mathrm{cPs}$. Diduga bahwa penambahan asam monokloro asetat yang terlalu banyak selain menyempurnakan reaksi substitusi juga berpengaruh terhadap terjadinya depolimerisasi, dalam hal ini pemutusan ikatan glikosida; apalagi proses eterifikasi

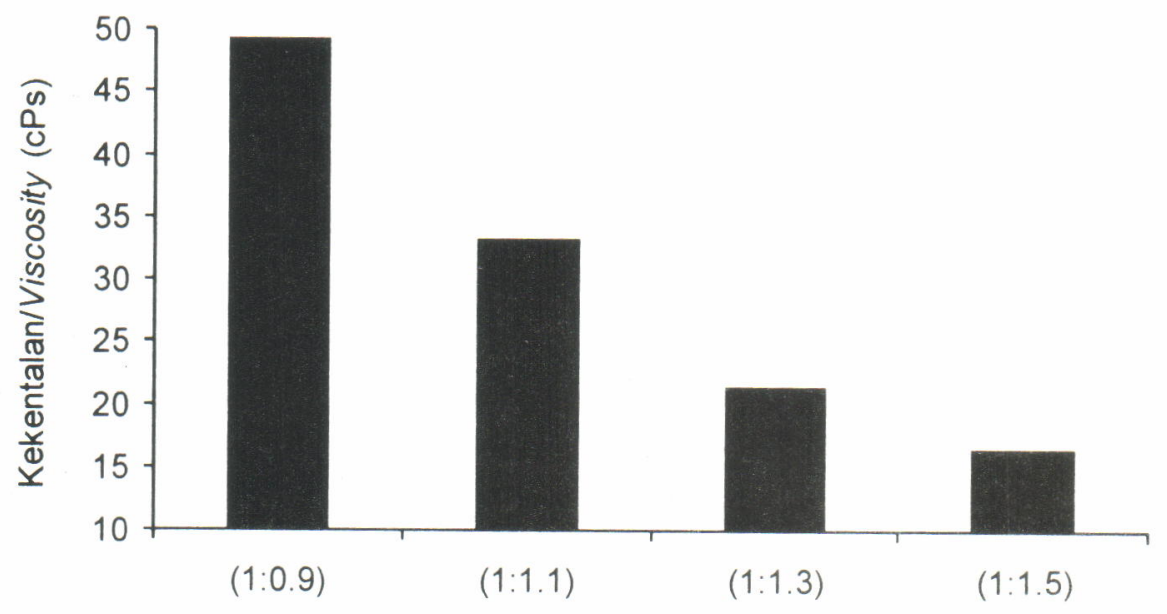

Rasio kitosan : asam monokloro asetat/ Ratio of chitosan : monochloro acetic acid

Gambar 6. Nilai kekentalan karboksimetil kitosan.

Figure 6. Viscosity of carboxymethyl chitosan. 
ini dilakukan pada suhu tinggi $\left(90^{\circ} \mathrm{C}\right)$. Akibatnya rantai polimer menjadi lebih pendek, berat molekul lebih rendah dan kekentalan yang terkait dengan berat molekul menjadi lebih rendah (Kyoon et al., 2003). Beberapa faktor yang dapat menyebabkan terjadinya pemotongan rantai polimer sehingga menyebabkan turunnya viskositas adalah suhu, waktu, enzim-enzim tertentu dan basa kuat (misalnya pada proses deasetilasi kitin dan alkalinisasi kitosan) (Rinaudo et al., 1992). Penurunan nilai kekentalan CMCts dipengaruhi pula oleh suhu eterifikasi yang diberikan. Kecepatan reaksi dapat meningkat dua kali lipat apabila suhu meningkat $10^{\circ}$ Kelvin setara dengan minus $263,16^{\circ} \mathrm{C}$ (Anon., 2004a). Disamping suhu, kecepatan reaksi juga meningkat dengan meningkatnya konsentrasi suatu bahan yang dicampurkan. Dalam percobaan ini kitosan alkalis yang mengandung ion $\mathrm{Na}^{+}$akan bersubstitusi dengan gugus karboksimetil $\left(-\mathrm{CH}_{2} \mathrm{COO}\right)$, ion $\mathrm{Na}^{+}$yang terlepas dari kitosan alkalis bereaksi dengan ion $\mathrm{Cl}$ yang dilepaskan oleh asam monokloro asetat membentuk garam $\mathrm{NaCl}$ dan asam glikolat.

Semakin tinggi konsentrasi asam monokloro asetat yang diberikan reaksi substitusi akan semakin cepat sehingga jumlah gugus karboksimetil yang berikatan dengan kitosan lebih banyak. Telah diketahui bahwa gugus karboksimetil merupakan gugus hidrofilik artinya mudah larut di dalam air. (Anon., 2004b). Hasil penelitian menunjukan bahwa nilai kekentalan kitosan sebelum dibuat CMCTs sebesar $571 \mathrm{cPs}$ tetapi setelah mendapatkan perlakuan eterifikasi nilai kekentalan turun yakni pada perlakuan rasio perbandingan kitosan : asam monokloro asetat 1:0,9 menjadi $49,3 \mathrm{cPs}$ (turun 521,75); pada perlakuan rasio perbandingan kitosan : asam monokloro asetat 1:1,1 menjadi $33 \mathrm{cPs}$ (turun $538 \mathrm{cPs}$ ); pada perlakuan rasio perbandingan kitosan : asam monokloro asetat 1:1,3 menjadi 21,38 cPs (turun 549,62 cPs) dan pada perlakuan rasio perbandingan kitosan : asam monokloro asetat $1: 1,5$ menjadi $16,38 \mathrm{cPs}$ (turun $554,62 \mathrm{cPs}$ ). Hasil uji regresi ditemukan persamaan garis logaritma $Y=24,239 \operatorname{Ln}(x)+521,74$ dengan nilai $r^{2}$ sebesar 0,9963 yang berarti peningkatan konsentrasi asam monokloro asetat selama proses eterifikasi dapat menurunkan nilai kekentalan $\mathrm{CMCts}$

\section{Nilai Derajat Substitusi (DS)}

Nilai DS pada hasil penelitian ini berkisar antara 0,89 sampai 0,99 ; tertinggi ditemukan pada perlakuan rasio kitosan : asam monokloro asetat $(1: 1,5)$ sebesar 0,996 dan terendah ditemukan pada perlakuan rasio kitosan : asam monokloro asetat $(1: 0,9)$ sebesar 0,892 . Pada Gambar 7 dapat dilihat nilai DS pada masing-masing perlakuan. Derajat substitusi (DS) menyatakan jumlah gugus hidroksil $\left(\mathrm{OH}^{-}\right)$kitosan pada satuan glukosamin yang disubstitusi oleh gugus karboksimetil $\left(-\mathrm{CH}_{2} \mathrm{COO}\right)$.

Pada Gambar 7 terlihat bahwa semakin tinggi asam monokloro asetat yang ditambahkan selama proses eterifikasi maka nilai DS semakin meningkat. Hasil uji regresi didapatkan persamaan garis linier $Y=$

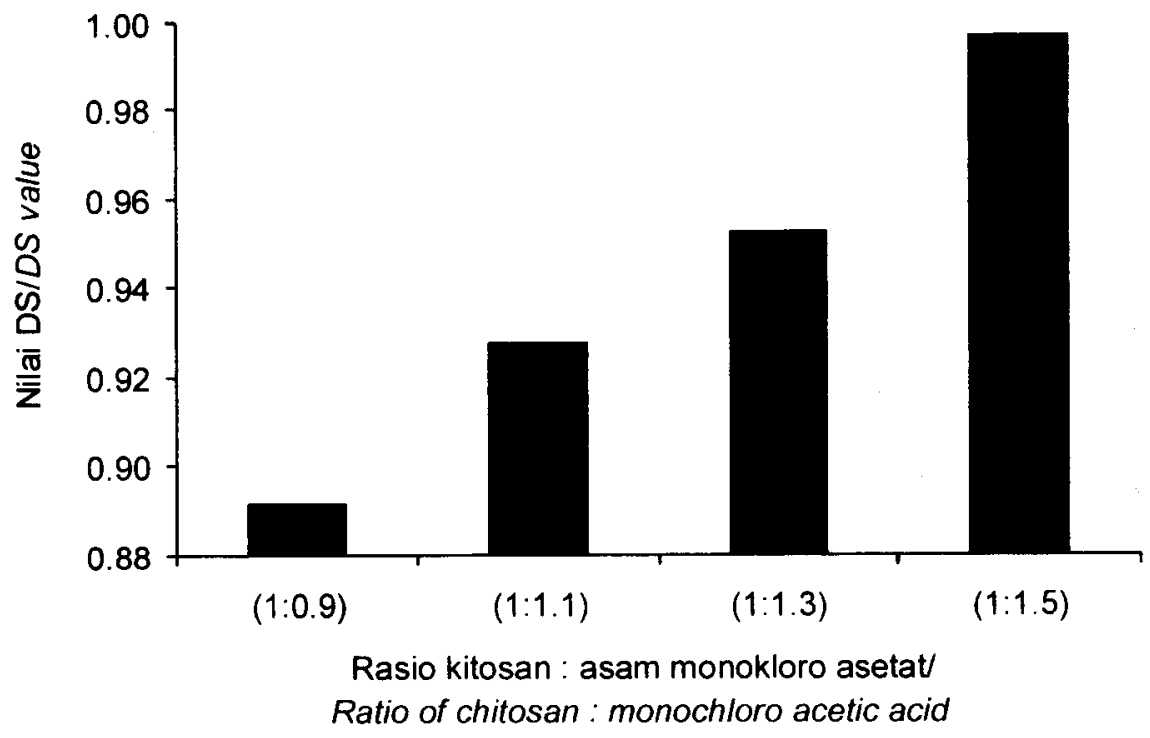

Catatan/Notes: DS (derajat substitusi/degree of substitution)

Gambar 7. Nilai derajat substitusi karboksimetil kitosan

Figure 7. Degree substitution of carboxymethyl chitosan. 
$0,034 X+0,8571$ dengan nilai $r^{2}$ sebesar 0,9896 . Konsentrasi asam monokloro asetat yang ditambahkan ke dalam kitosan selama eterifikasi pada suhu $90^{\circ} \mathrm{C}$ telah meningkatkan jumlah gugus hidroksil yang disubtitusi oleh gugus karboksimetil dari asam monokloro asetat. Derajat substitusi CMCts dilaporkan oleh Davies et al. (1989) berkisar antara 0,6 sampai 0,9, sedangkan Nudga et al., 1974; dalam Hayes, 1984 menghasilkan O-Karboksimetil kitosan dengan DS $\approx 1$. Selain itu Muzzarelli et al., 1982; dalam Hayes, 1984 melaporkan bahwa N-Karboksimetil kitosan bersifat larut dalam air meskipun DS-nya berkisar antara 0,25-1,0, demikian juga N,OKarboksimetil kitosan yang dilaporkan oleh Hayes (1984) mempunyai nilai DS 0,4-0,8 dan bersifat larut

\section{Nilai Kelarutan}

Tingkat kelarutan karboksimetil kitosan yang dihasilkan melalui proses karboksimetilasi dengan berbagai konsentrasi asam monokloro asetat disajikan pada Tabel 2. Dari data persen kelarutan yang menunjukkan banyaknya padatan (solute) untuk setiap $100 \mathrm{ml}$ larutan, dapat dihitung jumlah pelarut (air) untuk membuat larutan jenuh dari 1 gram CMCts (Tabel 2 kolom 3). Ada kecenderungan bahwa semakin tinggi jumlah asam monokloro asetat yang ditambahkan, semakin berkurang jumlah air yang diperlukan untuk melarutkan 1 bagian karboksimetil kitosan; yang berarti kelarutannya semakin baik. Meskipun demikian, berdasarkan Farmakope Indone-



Gambar 8. Ilustrasi ikatan gugus karboksimetil pada atom $C_{2}$ dan $C_{6}$

Figure 8. Illustration on the bounding position of carboxymethyl group on the atom $C_{2}$ and $C_{6}$.

dalam air. Sedangkan Ambarwaty et al. (2005) mendapatkan bahwa karboksimetil kitosan yang dihasilkan dari kitosan cangkang dan kaki rajungan mempunyai nilai DS $1,0-1,15$. Sebagaimana kekentalan, besarnya nilai DS karboksimetil kitosan dipengaruhi oleh jenis dan kualitas kitosan sebagai bahan bakunya serta kondisi proses karboksimetilasinya (suhu, waktu maupun jumlah monokloro asetat).

Peningkatan nilai DS akibat penambahan asam monokloro asetat yang semakin banyak dimungkinkan karena jumlah gugus karboksimetil ( $\mathrm{CH}_{2} \mathrm{COO}$ ) semakin banyak bereaksi dengan kitosan alkalis pada atom $\mathrm{C}_{6}$ (Kitosan-ONa) dan atom $\mathrm{C}_{2}\left(\right.$ Kitosan- $\mathrm{NH}_{2}$ ) seperti terlihat pada ilustrasi Gambar 8

Kelebihan gugus karboksimetil di dalam kitosan alkalis telah menyebabkan nilai DS lebih besar dari 0,9 seperti pada perlakuan rasio kitosan : asam monokloro asetat 1:1,5 yang telah menghasilkan nilai DS sebesar 0,99. sia, keempat konsentrasi asam monokloro asetat yang diterapkan menghasilkan karboksimetil kitosan dengan kriteria yang sama yaitu mudah larut. Hasil uji regresi menunjukkan adanya hubungan antara peningkatan jumlah asam monokloro asetat dengan persen kelarutan, dengan persamaan garis linier $Y=$ $2,327 X+7,49$ dengan nilai $r^{2}$ sebesar 0,9867

Nilai kelarutan memiliki pola yang sama dengan derajat substitusi. Semakin tinggi konsentrasi asam monokloro asetat yang ditambahkan, semakin tinggi nilai kelarutan dan DSnya; meskipun dalam pengelompokan keempat karboksimetil kitosan yang dihasilkan hampir memiliki kriteria kelarutan yang sama.

\section{KESIMPULAN DAN SARAN}

\section{Kesimpulan}

Konsentrasi asam monokloro asetat yang diberikan pada waktu proses eterifikasi sangat 
Tabel 2. Kelarutan karboksimetil kitosan dalam air

Table 2. Solubility of carboxymethyl chitosan in water

\begin{tabular}{|c|c|c|c|}
\hline $\begin{array}{l}\text { Rasio kitosan : } \\
\mathrm{ClCH}_{2} \mathrm{COOH} / \\
\text { Ratio of } \\
\text { chitosan to } \\
\mathrm{CICH} 2 \mathrm{COOH}\end{array}$ & $\begin{array}{l}\% \text { kelarutan (g solute } \\
\text { per } 100 \mathrm{ml} \text { la rutan }) / \% \\
\text { solubility }(\mathrm{g} \\
\text { solute/100 } \mathrm{ml} \\
\text { solution) }\end{array}$ & $\begin{array}{c}\text { Jumlah air yang } \\
\text { diperlukan untuk } \\
\text { melarutkan } 1 \mathrm{~g} \mathrm{CMCts} \\
(\mathrm{ml}) / \mathrm{Am} \text { mount of water } \\
\text { needed to dissolve } 1 \mathrm{~g} \text { of } \\
\text { CMCts }(\mathrm{ml})\end{array}$ & $\begin{array}{c}\text { Krite ria be rdasarkan } \\
\text { Fa rmakope } \\
\text { Indonesia/Criteria } \\
\text { based on Indonesian } \\
\text { Farmakope }\end{array}$ \\
\hline $1: 09$ & 10.15 & 9.85 & $\begin{array}{c}\text { Mudah larut/ } \\
\text { Easy to dissolve }\end{array}$ \\
\hline 1:1.1 & 11.7 & 8.55 & $\begin{array}{c}\text { Mudah larut/ } \\
\text { Easy to dissolve }\end{array}$ \\
\hline $1: 1.3$ & 14.36 & 6.96 & $\begin{array}{c}\text { Mudah larut/ } \\
\text { Easy to dissolve }\end{array}$ \\
\hline $1: 1.5$ & 17.02 & 5.88 & $\begin{array}{c}\text { Mudah larut/ } \\
\text { Easy to dissolve }\end{array}$ \\
\hline
\end{tabular}

berpengaruh terhadap kualitas dan kuantitas $\mathrm{CMCts}$ yang dihasilkan. Nilai terbaik berdasarkan nilai kekentalan dan kadar abu ditemukan pada perlakuan penggunaan asam monokloro asetat dengan rasio kitosan : asam monokloro asetat 1:0,9 (b/b) dengan nilai rendemen sebesar $129,4 \%$, kadar air $9,7 \%$, kadar abu $1,7 \%$, nilai kekentalan $49,3 \mathrm{cPs}$, tingkat kelarutan $9,85 \mathrm{ml}$ air $/ 1 \mathrm{~g}$ CMCts dan derajat subtitusi sebesar 0,89 .

\section{Saran}

Untuk memantapkan hasil yang diperoleh perlu dilakukan uji skala pilot plant sehingga hasil penelitian ini dapat dikomersialisasikan.

\section{DAFTAR PUSTAKA}

Ambarwaty, D., Wibowo, S., dan Fawzya, Y.N. 2005. Pengaruh rasio kitosan-monokloro asetat terhadap karboksimetil kitosan yang dibuat dari limbah rajungan. J. Penel. Perik. Indonesia. 11(4): 79-88.

Andales, S.C. 1981. Drying of Cereal Grains in the Philippines. Food Drying Proceedings of a Workshop Held at Edmonton, Alberta 6-9 July 1981. Sponsored by International Development Research Centre, Ottawa Canada. p. 51-60.

Anonim. 1995. Farmakope Indonesia. Edisi IV. Departemen Kesehatan Republik Indonesia. 1036 pp.

Anonymous. 1998. Annual Book of ASTM Standar. United States. 06.03.315
Anonymous. 2004a. Compound of Carboxymethyl chitosan. http://www.chitogenics.ns.ca/applicant.htm. Diakses 11 Maret 2004.

Anonymous. 2004b. Chemical Reaction and the effects of Temperature, Concentration and Catalyst. Htm. http://www. chemical reactivity. $h$ tm. Diakses 24 Maret 2004

Aumeilia, W. 2004. Pengaruh Jumlah Asam Monokloro Asetat dan Jenis Pelarut Organik Pengendap pada Pembentukan Karboksimetil Kitin. Skripsi. Fakultas Farmasi. Universitas Pancasila. Jakarta. 40 pp.

Basmal. J., Prasetyo, A. dan Farida, Y. 2005. Pengaruh Suhu Eterifikasi pada Pembuatan Karboksimetil kitosan. Proses Publikasi di Jurnal Penelitian Perikanan Indonesia.

Bader, H.J., and Birkholz, E. 1997. Teaching chitin chemistry. In Muzzarelli and Peter, M.G. (eds.). Chitin Handbook European Chitin Society. p. 507-519.

Davies, D.H., Elso, C.M. and Hayes, E.R. 1989. N,O-Carboxymethyl Chitosan, a New Water Soluble Chitin Derivative. In Gudmund Skjak-Braek, Anthosen, T. and Sandford, P. (eds.). Chitin and Chitosan. Elsevier Applied Science. 474 pp.

Dwiyitno, Basmal, J. dan Mulyasari. 2004. Suhu eterifikasi terhadap karakteristik karboksimetil kitosan (CMCts). J. Penel. Perik. Indonesia. 10(3): 67-74.

Hayes, E.R. 1984. N, O-Carboxymethyl Chitosan and Preparative Method Therefor. US Patents. 4,619,995. 7 pp.

Horwitzs, W. 1980. Official methods of Analysis of the Association of Afficial Analytical Chemist. Washington D.C. $1018 \mathrm{pp}$. 
Kyoon, N.H., Won, J.N., and Meyers, S.P. 2003. Effect of time/temperature treatment parameters on depolymerization of chitosan. J. Appl. Polys. Sci. 87: 1890-1894
Rinaudo, M., Le Dung, Pham and Milas, M. 1992. A New and Simple Method of Synthesis of Carboxymethyl chitosans. In Brine, C.J., Sandford, P.A. and Zikakis, J.P. (eds). Advances in Chitin and Chitosan. Elsevier Appl. Sci. p. 516-523. 